\title{
Fourier transform-infrared photoacoustic spectroscopy applied in fish scales to access environmental integrity: A case study of Astyanax altiparanae species
}

\author{
C.A. Santana ${ }^{\text {a }, ~ L . H . C . ~ A n d r a d e ~}{ }^{\text {a }}$, Y.R. Súarez ${ }^{\text {a }}$, K. Yukimitu ${ }^{\text {b }}$, J.C.S. Moraes ${ }^{\text {b }}$, S.M. Lima ${ }^{\mathrm{a}, *}$ \\ ${ }^{a}$ Programa de Pós-Graduação em Recursos Naturais, Universidade Estadual de Mato Grosso do Sul, C.P. 351, Dourados, MS, Brazil \\ ${ }^{\mathrm{b}}$ Universidade Estadual Paulista, Departamento de Física e Química, Av. Brasil 56, 15385-000, Ilha Solteira, SP, Brazil
}

\section{H I G H L I G H T S}

- Monitoring the environmental integrity by FTIR-PAS.

- Fish scales of Astyanax altiparanae as bioindicator.

- Fish scales as bioindicator for intraspecific study.

\section{A R T I C L E I N F O}

\section{Article history:}

Received 19 January 2015

Available online 20 July 2015

\section{Keywords:}

Bioindicators

Chemical vibrational modes

Fish collagen

Mid-infrared absorption spectroscopy

Multivariate statistical analysis

\begin{abstract}
A B S T R A C T
Fish scales have been used to differentiate fish species and to give information on water pollution, besides others different purposes. In the present work, we are proposing, for the first time to our knowledge, to available the absorption from fish scales with Fourier Transform Infrared Photoacoustic Spectroscopy (FTIR-PAS) to assess the environmental integrity of different habitats. The infrared absorption measurements were performed directly on fish scales from the Astyanax altiparanae species, in order to check if the scales, and consequently the species, can be used as environmental bioindicator. The main absorption intensities were used as variables in the multivariate statistical analysis. It was noted that the chemical composition of the scales is directly related to the available food in the habitats, which is related to the integrity level of the environmental. The results point the fish scales as bioindicator to be applied with FTIR-PAS for monitoring aquatic ecosystems.
\end{abstract}

(c) 2015 Elsevier B.V. All rights reserved.

\section{Introduction}

Streams are in general, aquatic ecosystems of small extensiveness with well-defined characteristics. Because of their limited flow, they are strongly sensitive to anthropogenic actions [1,2]. In streams, the impacts of these actions lead to the loss of integrity in the ecosystem, which is commonly evaluated through water quality tests of the dissolved oxygen, $\mathrm{pH}$, temperature, electrical conductivity and through the physical structure of the habitat [3]. However, in some cases, these parameters are not sufficient to evaluate the ecosystem integrity, indicating that the search for other biological indicators must be encouraged.

\footnotetext{
* Corresponding author at: Universidade Estadual de Mato Grosso do Sul - UEMS, Programa de Pós-Graduação em Recursos Naturais - PGRN, Grupo de Espectroscopia Óptica e Fototérmica - GEOF, CEP 79804-970 - C.P. 351, Dourados, MS, Brazil. Tel.: +55 673902 2653; fax: +55 6739022652 .

E-mail address: smlima@uems.br (S.M. Lima).
}

Due their sensitivity and responsiveness to changes in water, aquatic organisms have been used as bioindicators [4]. Among them, fishes are those of great interest, mainly because they bioaccumulate substances of the environment [5]. Different fish species (or their parts, such as scales) have been extensively explored at the literature as bioindicators [3,6]. It is well known that fish scales consist of different organic compounds, water and minerals, and they have two distinct faces: the so-called inside face, which is smooth, fibrillar and contains a higher concentration of collagen; and the outside face, which is bony and rough, and is composed of a single mineral phase of calcium deficient hydroxyapatite [7-10]. Environmental reports of fish scales are gaining importance, mainly in the use of scales for determining fish diet, phylogeny, DNA extraction, differentiation of species, sexual dimorphism, growth and the pollution status of the water body [4,12-20]. However, most of these studies use only morphometric measurements to obtain and interpret the results. 
Fourier Transform Infrared Photoacoustic Spectroscopy (FTIRPAS) is an efficient and versatile technique that, combined with multivariate statistical analysis, has provided different studies in biological systems samples [21,22]. The technique has been applied in studies of fungi and bacteria [23-25] and more recently was employed to identify plant diseases [26], to differentiate castes and species of ants $[27,28]$, to characterize the pheromones of wasps [29] and to differentiate fish species by analyzing directly the fish scales [18]. Particularly, in the study performed by Almeida et al. [18] the FTIR-PAS analysis showed that the protein concentration of the scales is directly related to the diet and showed that the methodology can verify the influence of environmental characteristics on the metabolism of the fish.

In this work we propose to apply, for the first time to our knowledge, the FTIR-PAS directly in fish scales in order to access differences in their chemical composition and relate them with the environmental characteristics. Scales of Astyanax altiparanae species was chosen to the research because it has great adaptive exploratory capacity and a wide geographical distribution, which classify the species as bioindicator [30]. Then, considering that all potential water contaminants or compounds that alter biological/chemical water characteristics can interfere in fish physiology, which is reflected directly in the fish scales composition, our study aimed to verify the potentiality of the methodology applied in scales of $A$. altiparanae species in order to classify the scales as bioindicators.

\section{Materials and methods}

The fishes were sampled in three streams (stream \#1: "Curral de Arame," stream \#2: "Laranja Doce," and stream \#3: “Água Boa") from the Ivinhema River Basin, Upper Paraná River, Brazil (Fig. 1). These selected streams have their own characteristics and can be distinguished by integrity level using as reference the habitats conditions, such as riparian vegetation, dissolved oxygen concentration and electrical conductivity. Stream \#1 is defined to have high integrity, because its source is far from an urban area (Fig. 1), it has preserved riparian vegetation, with high dissolved oxygen concentration $\left(\sim 7.3 \mathrm{mg} \mathrm{L}^{-1}\right)$ and the electrical conductivity of the water is approximately $73 \mu \mathrm{S} \mathrm{cm}^{-1}$; stream \#2 is considered to be moderately impacted, although its source is away from an urban area (Fig. 1), it has a riparian vegetation that is not totally preserved. The electrical conductivity of the water for this stream is $\sim 161 \mu \mathrm{S} \mathrm{cm}^{-1}$, which is considerably higher ( $\sim 61 \%$ greater than the limit established by the "Norma Técnica da Companhia
Ambiental do Estado de São Paulo" [31]) and dissolved oxygen concentration of approximately $6.9 \mathrm{mg} \mathrm{L}^{-1}$, and part of its course crosses an urban area. Stream \#3 is definitely the most highly impacted stream, because its fount is within the Dourados urban area (Fig. 1), and its water electrical conductivity is $\sim 343 \mu \mathrm{S} \mathrm{cm}^{-1}$ ( $\sim 3.4$ times higher than the established limit) with low dissolved oxygen concentration $\left(\sim 4.5 \mathrm{mg} \mathrm{L}^{-1}\right)$. The course of stream \#3 is noted by the presence of underwood, and much of the riparian vegetation is degraded. Stream \#3 receives anthropogenic influence, including sewage and waste discharge from the urban area.

Immediately after being collected, the fishes were fixed in $10 \%$ formalin to be transfer to the laboratory, where they were transferred to bottles of $70 \%$ alcohol. From each stream, 15 fishes were selected, and we removed 5 scales from the humeral portion of each fish, totaling 45 fishes and 225 scales. Based on infrared spectroscopic preliminary analyzes, the humeral region was chosen to exhibit more intense absorption peaks of its chemical composition. After removal, the scales were washed in distilled water, sandwiched between glass slides and were placed in an oven at $60^{\circ} \mathrm{C}$ for $40 \mathrm{~min}$. Before analysis in the infrared spectrophotometer, the scales were kept in a vacuum oven for $48 \mathrm{~h}$ to remove all humidity.

FTIR-PAS was performed with a Nexus 670 spectrophotometer from Thermo Nicolet linked to a photoacoustic cell for detection in the spectral range from 4000 to $400 \mathrm{~cm}^{-1}$, which covers the fingerprint spectral region (1700 and $400 \mathrm{~cm}^{-1}$ ). Throughout the experiment, the spectrophotometer was purged with dry air and the photoacoustic cell was purged with helium gas. A carbon black reference was used for background correction, and a new reference background spectrum was taken for each of the eight spectra, with a resolution of $16 \mathrm{~cm}^{-1}$ and 128 scans for each sample. The spectra were initially collected for both the internal and external faces of the scales.

From the obtained spectra, 11 more intense absorption peaks in the midinfrared region were chosen, and the relative absorption intensities of the peaks were separated in a matrix for statistical analyses, in which the wavenumber of each peak was used as variable. Discriminant function analysis was used, so a linear combination of variables that best explain the differentiation between scales could be found [32]. In this specific case, the statistics were used to relate the chemical composition due amide composition obtained from the scales, to the environmental integrity of the streams.

A scanning electron microscopy (SEM), a ZEISS EVO LS-15 equiped with one Oxford Inca x-act detector (Oxford Instruments, Abingdon, Oxfordshire, UK) for energy dispersive

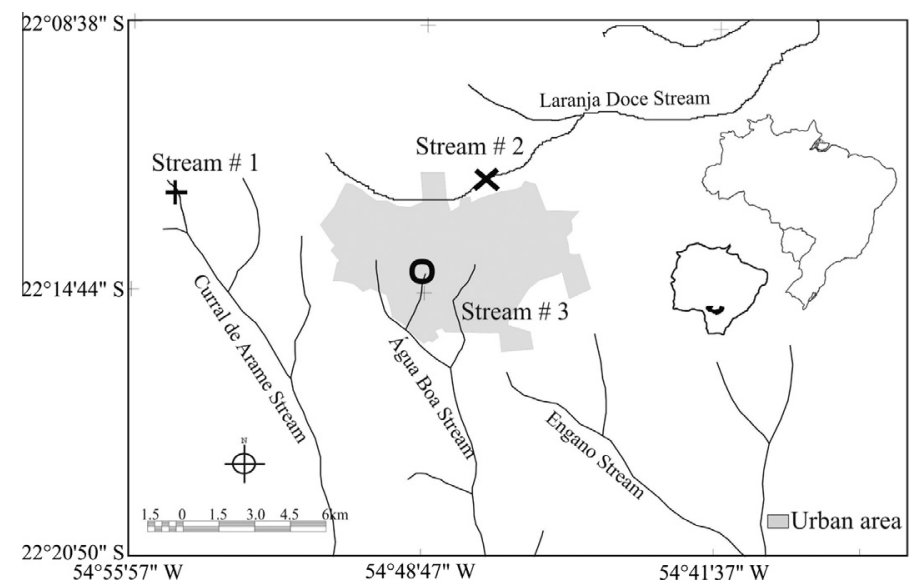

Fig. 1. Map indicating the three streams where the A. altiparanae specie were collected. 
microanalysis (EDS), was used to obtain images of the scales and chemical composition information. For this, the scales were fixed in the sample holder with Carbon and a thin Au was deposited on each inside and outside faces of the scales.

\section{Results and discussion}

The average of the photoacoustic absorption spectra obtained for scales of the A. altiparanae species, sampled in the three studied streams, shows that the inside and outside faces from stream \#1 exhibit very similar spectra whereas the spectra for streams \#2 and \#3 are quite different (Fig. 2). This is related to the heat diffusion length in a sample, $\mu_{s}$, during the photoacoustic measurement. The $\mu_{s}$ value represents the sample thickness that is contributing to the absorption signal, which in our case means that it depends on the thicknesses of scales. As is known, $\mu_{s}$ is proportional to the thermal diffusivity of the material, $\alpha\left(\mu \mathrm{m}^{2} / \mathrm{s}\right)$, and inversely proportional to the modulation frequency of the incident light, $f\left(\mathrm{~s}^{-1}\right)$, so that these parameters are connected by the equation $\mu_{s}=(\alpha / \pi f)^{0.5}$ [33]. In our procedure, these parameters were used for the extremes $f=1264$ and $126.4 \mathrm{~Hz}$. By estimating $\alpha \sim 2.2 \times 10^{5} \mu \mathrm{m}^{2} / \mathrm{s}$ (approximately the natural nanostructured hydroxyapatite thermal diffusivity [34]), it can be expected that the depth $\mu_{s}$ is between 7 and $24 \mu \mathrm{m}$ in our samples. In this case, for the scales from fish collected in stream \#1, the average thicknesses $(28 \pm 2$ ) $\mu \mathrm{m}$ is closer to $\mu_{s}$ estimated value, indicating that infrared absorption analysis are not able to distinguish between both faces of the scales. The same was not observed for the scales from fishes sampled in streams \#2 and \#3 because the average thicknesses of the scales were ( $82 \pm 8$ ) and $(96 \pm 5) \mu \mathrm{m}$, respectively, which are bigger than $\mu_{s}$.

To better understand the main responsible for different absorptions in each face of scale, SEM images were obtained for inside ((a), (c) and (e)) and outside ((b), (d) and (f)) faces of scales from each stream (Fig. 3). By the images can be noted a similarity among inside faces for the scales from the three streams, and also among inside (a) and outside (b) faces for scales from fished collected in the stream \#1. This fibrillary layer is characteristic from collagen fibers and is expected for inside face of scales or for scales extracted of young fishes, in which the osseous structure is less pronounced. The superficial osseous layer is expected to be observed in the outside face ((d) and (f) for streams \#2 and \#3, respectively) of the scale. So, it is possible to state that fish scales of stream \#1 has low superficial osseous layer, probably due the fishes from this stream are younger.

The SEM images together with the FTIR-PAS indicates that the collagen concentration in a scale is in highest concentration in

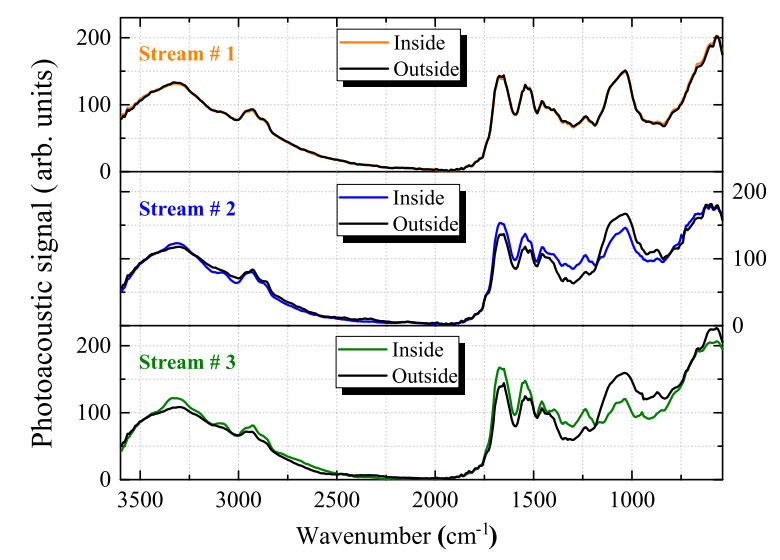

Fig. 2. Average photoacoustic spectra from inside and outside faces for scales of the A. altiparanae specie, from the streams \#1, \#2 and \#3. the inside face and it can be observed in scales from all studied fish samples. Because this result we decided to investigate the inside scale face to investigate the vibrational modes of collagen in the scales. Furthermore, once hydroxyapatite concentration is not evident in all scales sampled, the portion around $1000 \mathrm{~cm}^{-1}$ in the infrared spectra were not considered for statistical analysis; only the absorption peaks with wavenumber higher than $1200 \mathrm{~cm}^{-1}$ were considered, which represent the composition of collagen (amide and amine).

The average spectra of the inside face for each stream are plotted to indicate with arrows the absorption peaks (vibrational modes) that were selected for statistical analysis (Fig. 4). The functional groups of these peaks were identified from reference data (Table 1) [11,35]. For each stream, the peak intensity values were used to assemble a matrix for multivariate statistical analysis. From this analysis, the first and second canonical roots were obtained with the $F$ and $p$ factors for each variable (functional group) (Table 1 ).

The dispersion diagram for the first and second canonical roots of the statistical analysis were determined (Fig. 5), from which Wilk's Lambda $=0.40, F=11.552$, and $p<0.001$. This result showed a significant difference between the fish scales from different streams; the first canonical is the most significant root, explaining $81.5 \%$ of the variation in the data, and the second canonical root explains $18.5 \%$ of the variation. Together, both canonical roots explained $100 \%$ of the results, and this complete explanation is very significant in the description of a natural system.

Based on the statistical interpretation, the observed separation in the first canonical root is associated with differences in the absorption intensities of the main chemical functional groups of the scales. It reflects very well the streams characteristics described before, indicating correspondences between the available foods in streams with the scales chemical composition. This evidence can be confirmed by interpreting the 11 peaks selected for statistical analysis, since four of them were most significant: 1234, 1396, 2969 and $3309 \mathrm{~cm}^{-1}$. Between them, only the $1234 \mathrm{~cm}^{-1}(\mathrm{C}-\mathrm{N}=$ Amide $\mathrm{III})$ and $2969 \mathrm{~cm}^{-1}\left(\mathrm{CH}_{3}\right)$ peaks were the most important in explicating the separation of the first canonical root: the peak at $1234 \mathrm{~cm}^{-1}$ was responsible for moving the ellipse for stream \#3 to the positive side in the first canonical root; this shift is caused by the feeding habits or the food types that are available in the environment, which is known to have a strong influence on a great number of fish species [36,37]. It can be expected that protein concentration is in excess in stream \#3, because the water has a higher electrical conductivity and consequently, a greater accumulation of organic matter.

In the opposite direction, the peak at $2969 \mathrm{~cm}^{-1}\left(\mathrm{CH}_{3}\right)$ was significant in the first canonical root for stream \#1, because it brought the ellipse to the negative side. This functional group is related to the radical protein compounds: the higher rate of $\mathrm{CH}_{3}$ in the fish scales from stream \#1 indicates that there is a greater accumulation of this compound in the collagen structural chain, more than found in the fish from the other two streams. This accumulation is associated with the low calcination of these scales and is also from the greater quantity of food that has $\mathrm{CH}_{3}$ as a component. Ibañez et al. [20] found that the availability, type of food and the different environments in which the fish is inserted are parameters sufficient to cause differences in the scale. The authors noted that in less impacted sites, as our stream \#1, an increase is observed in the consumption of aquatic and terrestrial arthropods followed by algae and sediment, and in more impacted sites, the most significant food resources were sediments and terrestrial plants. This difference can influence the observed in the concentration of $\mathrm{CH}$ vibrational modes analyzed by FTIR-PAS.

EDS analyses were performed to quantify the concentration of $\mathrm{C}$ and $\mathrm{N}$ from SEM images of scales inside faces ((a), (c) and (e) in 

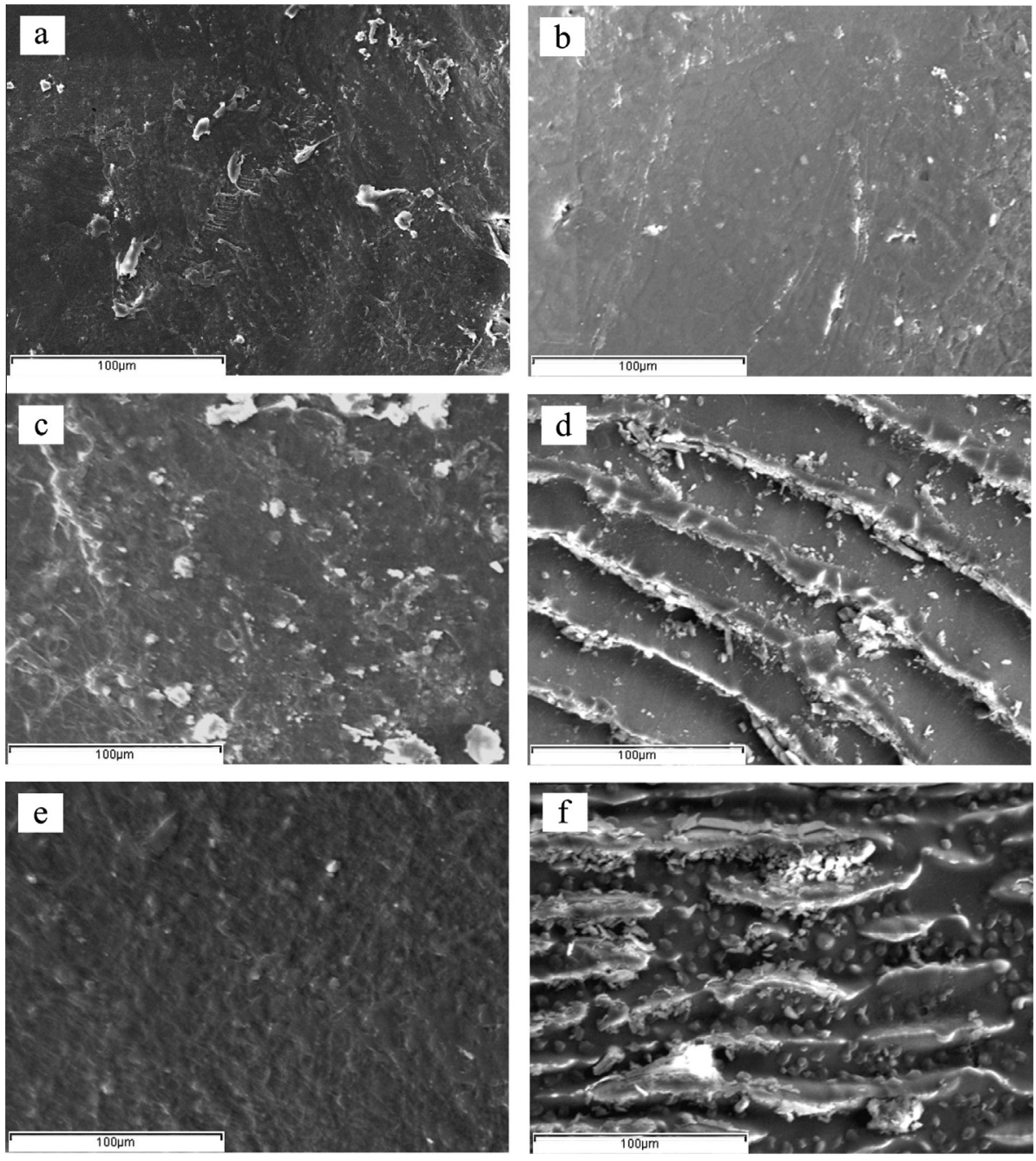

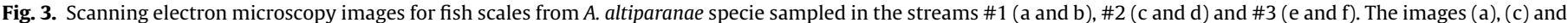
(e) represents the inside faces and the (b), (d) and (f) represents the outside faces.

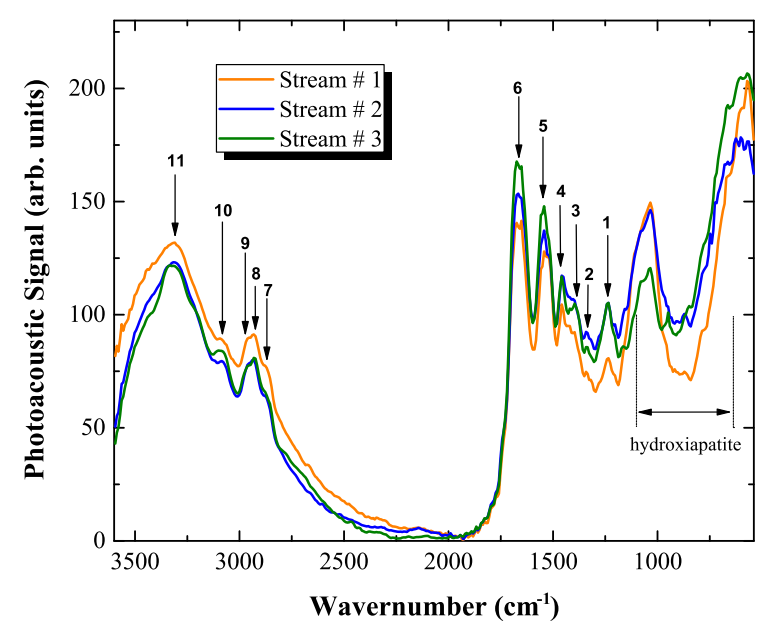

Fig. 4. Average photoacoustic spectra from inside faces for scales of the $A$. altiparanae specie, from the streams \#1, \#2 and \#3.

Fig. 3) from streams \#1, \#2 and \#3. The results shown that fish scales from stream \#1 have concentration of Carbon around $60 \mathrm{wt} . \%$, which is approximately $20 \%$ higher than those ones from streams \#2 and \#3 ( 50 wt.\%). This agrees with the statistical interpretation described above, which showed that the scales from stream \#1 are localized in the left side of the dispersion diagram (Fig. 5) due the $v_{a s} \mathrm{CH}_{3}$. By other side, fish scales from stream \#3 exhibit concentration of Nitrogen approximately 1.6 times higher than those ones from streams \#1, which also corroborates to the statistical analyses: $v_{\mathrm{s}} \mathrm{C}-\mathrm{N}$ functional group is responsible to bring the ellipse for stream \#3 to the positive side in Fig. 5.

It is well known that biotic and abiotic variations lead to change in the diet of fish, and many fish species change their diets based on environmental factors. Therefore, the availability of food depends on the condition of the environment in which the individual is inserted and this variation particularly occurs in species that have higher food plasticities, such as A. altiparanae [3,37]. Ibañez et al. [20] stated that the morphology and chemical composition of fish scales can be adjusted by seasonal, location or habitat variability and also by availability and characteristics of food, leading to a differentiation of phenotypic characteristics.

The influence of food is so significant that it is directly linked to the protein and lipids content, or to the other chemical properties of the body or from the tissue $[38,39]$. Essential amino acids shape the amide proteins to maintain the cellular functions of the organisms, and some of these amino acids are not produced directly by the organism but must be acquired through food. Therefore, not only the presence of the food and its availability in the environment but also the chemical of food is important to the organism 
Table 1

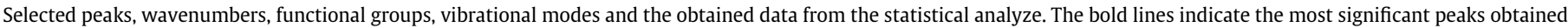
by the statistical analysis.

\begin{tabular}{|c|c|c|c|c|c|c|c|}
\hline Peaks & Wavenumber $\left(\mathrm{cm}^{-1}\right)$ & Functional group & Vibrational mode & Root 1 & Root 2 & $F$ & $p(<0.05)$ \\
\hline 1 & 1234 & $v_{s} \mathrm{C}-\mathrm{N}$ (Amide III) & Stretch & 2.419 & 0.163 & 8.699 & 0.001 \\
\hline 2 & 1334 & $v_{\text {as }} \mathrm{CNH}$ (Amide II) & Stretch-open, cis & -0.354 & 0.185 & 0.578 & 0.566 \\
\hline 3 & 1396 & $\delta \mathrm{C}-\mathrm{N}$ (Amide I) & Stretch & -2.776 & 1.644 & 7.007 & 0.002 \\
\hline 4 & 1457 & $\delta \mathrm{CNH}$ (Amide II) & Stretch-bend, cis & 1.247 & -0.561 & 2.156 & 0.132 \\
\hline 5 & 1542 & $\delta \mathrm{CNH}$ (Amide II) & Stretch-bend, trans & 0.650 & -1.930 & 2.539 & 0.094 \\
\hline 6 & 1666 & $v \mathrm{C}=\mathrm{O}$ (Amide I, II and III) & Stretch & -0.171 & 0.674 & 0.393 & 0.677 \\
\hline 7 & 2877 & $v_{\mathrm{s}} \mathrm{CH}_{3}$ & Symmetric stretching & 2.132 & -1.246 & 2.007 & 0.150 \\
\hline 8 & 2931 & $v_{\text {as }} \mathrm{CH}_{2}$ & Antisymmetric stretching & 1.513 & -2.731 & 1.690 & 0.200 \\
\hline 9 & 2969 & $v_{\text {as }} \mathrm{CH}_{3}$ & Antisymmetric stretching & -5.203 & 3.168 & 13.349 & 0.001 \\
\hline 10 & 3077 & $v_{\text {as }} \mathrm{NH}_{2}$ (Amide B) & Antisymmetric stretching & 1.472 & -0.180 & 1.367 & 0.269 \\
\hline 11 & 3309 & $v_{\mathrm{s}} \mathrm{N}-\mathrm{H}$ (Amide II also called Amide A) & Stretch trans & 0.790 & 1.640 & 3.728 & 0.035 \\
\hline
\end{tabular}

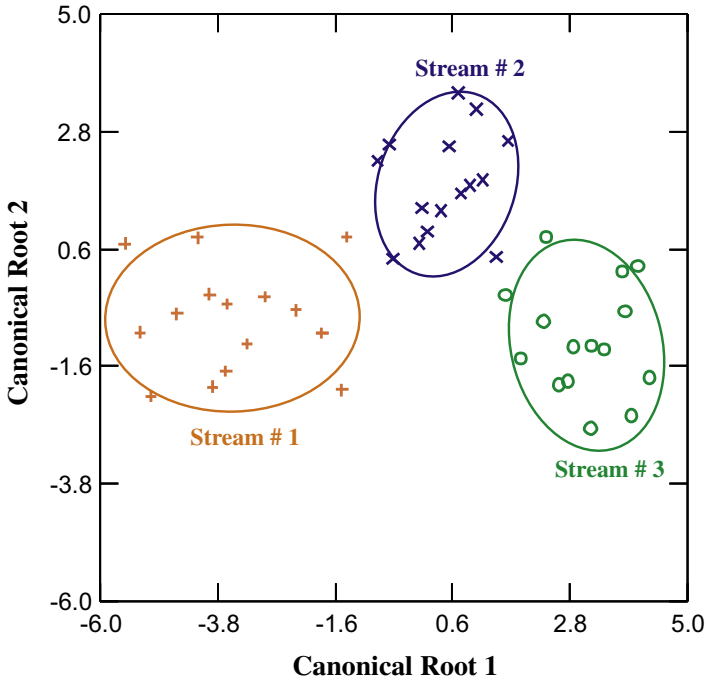

Fig. 5. Dispersion diagram determined by the statistical analyzes.

$[37,40]$. A altiparanae fish species is considered to be omnivorous, i.e., it eats plants and animals in balanced proportions, and this species is also generalist/opportunistic because it can feed on different food items in its diet [41,42]. This characteristic indicates that it can consume several food types, such as detritus/sediments, plants and insects. Souza and Lima-Junior [3] found in their study of the diet of A. altiparanae that food consumed by this species may differ based on the quality of the environment in which the species is inserted.

The second canonical root differentiated the streams according to the sub-basin to which the streams belong. In this sense, although all of the streams belong to the Ivinhema River Basin, Upper Paraná River, streams \#1 and \#3 are tributaries of the Dourados River, whereas stream \#2 is a tributary of the Brilhante River. These sub-basins are separated by approximately $200 \mathrm{~km}$, which can generate isolation and subsequent genetic differentiation between these analyzed subpopulations. This assumption will be confirmed in the future by considering more sub-basins of the Ivinhema River Basin.

\section{Conclusions}

The results showed that scales of A. altiparanae species is an appropriate bioindicator for environmental monitoring when their chemical composition is investigated directly by the Fourier Transform Infrared Photoacoustic Spectroscopy combined with multivariate statistical analysis. The used methodology is an efficient and very important tool for analyzing differences in the chemical composition of fish scales, which are related to the environmental conditions.

\section{Conflict of interest}

There is no conflict of interest.

\section{Acknowledgements}

The authors would like to thank Agência Brasileira de Inovação (FINEP), Coordenação de Aperfeiçoamento de Pessoal de Nível Superior (CAPES), Conselho Nacional de Desenvolvimento Científico e Tecnológico (CNPq) and Fundação de Apoio ao Desenvolvimento do Ensino, Ciência e Tecnologia do Estado de Mato Grosso do Sul (FUNDECT) for their financial support.

\section{References}

[1] A.M. Cunico, J.D. Allan, A.A. Agostinho, Functional convergence of fish assemblages in urban streams of Brazil and the United States, Ecol. Indic. 11 (2011) 1354-1359.

[2] A. Peressin, M. Cetra, Responses of the ichthyofauna to urbanization in two urban areas in Southeast Brazil, Urban Ecosyst. (2014), http://dx.doi.org/ 10.1007/s1125-014-0352-5.

[3] R.G. Souza, S.E. Lima-Junior, Influence of environmental quality on the diet od Astyanax in a microbasin of central western Brazil, Acta Sci. Biol. Sci. 35 (2) (2013) 177-184.

[4] R. Kaur, A. Dua, Fish scales as indicators of wastewater toxicity from an international water Tung Dhab drain, Environ. Monit. Assess. 184 (2012) 2729-2740.

[5] Y.B.M. Koca, S. Koca, S. Yildiz, B. Gurcu, E. Osanc, O. Tuncbas, et al. Investigation of histopathological and cytogenetic effects on Lepomis gibbosus (pisces: Perciformes) in the Cine stream (Aydin/Turkey) with determination of water pollution, Environ. Toxicol. 20 (2005) 560-571.

[6] L. Casatti, R.M. Romero, F.B. Teresa, J. Sabino, F. Langeani, Fish community structure along a conservation gradient in Bodoquena Plateau streams, central West of Brazil, Acta Limnol. Bras. 22 (2010) 50-59.

[7] T. Ikoma, H. Kobayashi, J. Tanaka, D. Walsh, S. Mann, Microstructure, mechanical, and biomimetic properties of fish scales from Pagrus major, J. Struct. Biol. 142 (2003) 327-333.

[8] F.G. Torres, O.P. Troncoso, J. Nakamatsu, C.J. Grande, C.M. Gómez, Characterization of the nanocomposite laminate structure occurring in fish scales from Arapaima Gigas, Mater. Sci. Eng. C 28 (2008) 1276-1283.

[9] F. Pati, B. Adhikari, S. Dhara, Isolation and characterization of fish scale collagen of higher thermal stability, Bioresour. Technol. 101 (2010) 3737 3742.

[10] H. Mori, Y. Tone, K. Shimizu, K. Zikihara, S. Tokutomi, T. Ida, H. Ihara, M. Hara, Studies on fish scale collagen of Pacific saury (Cololabis saira), Mater. Sci. Eng. C 33 (2013) 174-181.

[11] D. Lin-Vien, N.B. Colthup, W.G. Fateley, J.G. Grasselli, Infrared and Raman Characteristic Frequencies of Organic Molecules, Academic Press, San Diego, New York, Boston, London, Sydney, Tokyo, Toronto, 1991.

[12] N. Kaur, A. Dua, Species specificity as evidenced by scanning electron microscopy of fish scales, Curr. Sci. 87 (2004) 692-696.

[13] N. Poulet, Y. Reyol, H. Collier, S. Lek, Does fish scale morphology allow the identification of populations at a local scale? A case study for rostrum dace Leuciscus leuciscus burdigalensis in River Viaur (SW France), Aquat. Sci. 67 (2005) 122-127. 
[14] R. Kumar, P.J. Singh, N.S. Nagpure, B. Kushwaha, S.K. Srivastava, W.S. Lakra, A non-invasive technique for rapid extraction of DNA from fish scales, Indian J. Exp. Biol. 45 (2007) 992-997.

[15] D.R. Khanna, P. Sarkar, A. Gautma, R. Bhutiani, Fish scales as bio-indicator of water quality of River Ganga, Environ. Monit. Assess. 134 (2007) 153-160.

[16] H.R. Esmaeili, Z. Gholami, Scanning Electron Microscopy of the scale morphology in Cyprinid fish, Rutilus frisii kutum Kamenskii, 1901 (Actinopterygii: Cyprinidae), Iran. J. Fish. Sci. 10 (1) (2011) 155-166.

[17] A.L. Ibañez, I.G. Cowx, P. O'Higgins, Geometric morphometric analysis of fish scales for identifying genera, species, and local populations within the Mugilidae, Can. J. Fish. Aquat. Sci. 64 (2007) 1091-1100.

[18] F.S. Almeida, S.M. Lima, L.H.C. Andrade, Y.R. Súarez, Differentiation of neotropical fish species with statistical analysis of fourier transform infrared photoacoustic spectroscopy data, Appl. Spectrosc. 66 (7) (2012) 782-785.

[19] A.L. Ibañez, I.G. Cowx, P. O'Higgins, Variation in elasmoid fish scale patterns is informative with regard to taxon and swimming mode, Zool. J. Linn. Soc. 155 (2009) 834-844.

[20] A.L. Ibañez, E. Pacheco-Almanzar, I.G. Cowx, Does compensatory growth modify fish scale shape?, Environ Biol. Fish. 94 (2012) 477-482.

[21] M. Hofman, S. Pasieczna-Patkowska, J. Ryczkowski, L. Wachowski, Identification of functional groups on the surface of modified organic materials using the FT-IR/PAS method, Eur. Phys. J. Spec. Top. 154 (2008) 325-328.

[22] D. Changwen, Z. Guiqin, Z. Jianmin, W. Huoyan, C. Xiaoqin, D. Yuanhua, W. Hui, Characterization of animal manures using mid-infrared photoacoustic spectroscopy, Bioresour. Technol. 101 (2010) 6273-6277.

[23] S.E. Thompson, N.S. Foster, T.J. Johnson, N.B. Valentine, J.E. Amonette, Identification of bacterial spores using statistical analysis of fourier transform infrared photoacoustic spectroscopy data, Appl. Spectrosc. 57 (2003) 893-899.

[24] H. Zhao, R.L. Parry, D.I. Ellis, G.W. Griffith, R. Goodacre, The rapid differentiation of Streptomyces isolates using Fourier transform infrared spectroscopy, Vib. Spectrosc. 40 (2006) 213-218.

[25] M. Nie, W.Q. Zhang, M. Xiao, J.L. Luo, K. Bao, J.K. Chen, B. Li, FTIR Spectroscopy and artificial neural network identification of Fusarium species, J. Phytopathol. 155 (2007) 364-367.

[26] L.H.C. Andrade, P.G. Freitas, B.G. Mantovani, M.S. Figueiredo, R.A. Lima, S.M. Lima, M.A.S. Rangel, R.M. Mussury, Detection of soybean rust contamination in soy leaves by FTIR photoacoustic spectroscopy, Eur. Phys. J. Spec. Top. 153 (2008) 539-541.

[27] W.F. Antonialli Junior, S.M. Lima, L.H.C. Andrade, Y.R. Súarez, Comparative study of the cuticular hydrocarbon in queens, workes and males of Ectatomma vizottoi (Hymenoptera, Formicidae) by Fourier transform-infrared photoacoustic spectroscopy, Genet. Mol. Res. 6 (3) (2007) 492-499.
[28] W.F. Antonialli-Junior, Y.R. Súarez, T. Izida, L.H.C. Andrade, S.M. Lima, Intra and interspecific variation of cuticular hydrocarbon composition in two Ectatomma species (Hymenoptera: Formicidae) based on Fourier transform infrared photoacoustic spectroscopy, Genet. Mol. Res. 7 (2) (2008) 559566.

[29] E.F. Neves, L.H.C. Andrade, Y.R. Súarez, S.M. Lima, W.F. Antonialli-Junior, Agerelated changes in the surface pheromones of the wasp Mischocyttarus consimilis (Hymenoptera: Vespidae), Genet. Mol. Res. 11 (3) (2012) 18911898.

[30] F.C.T. Lima, L.R. Malabarba, P.A. Buckup, et al., Genera Incertae Sedis in Characidae, in: R.E. Reis, S.O. Kullander, C.J. Ferraris Jr. (Eds.), Checklist of the Freshwater Fishes of South and Central America, EDIPUCRS, Porto Alegre, Brasil, 2003, pp. 106-168.

[31] Cetesb, Companhia Ambiental do Estado de São Paulo, 2008, Internet, <http:// www.cetesb.sp.gov.br>.

[32] G.P. Quinn, M.J. Keough, Experimental Design and Data Analysis for Biologists, Cambridge University Press, Edinburgh, 2005.

[33] K.H. Michaelian, Photoacoustic Infrared Spectroscopy, John Wiley \& Sons Inc., Hoboken, New Jersey, 2010.

[34] T.M. Coelho, E.S. Nogueira, W.R. Weinand, W.M. Lima, A. Steimacher, A.N. Medina, et al., Thermal properties of natural nanostructured hydroxyapatite extracted from fish bone waste, J. Appl. Phys. 101 (2007) 084701, http:// dx.doi.org/10.1063/1.2718866.

[35] D.W. Mayo, F.A. Miller, R.W. Hannah, Course Notes on the Interpretation of Infrared and Raman Spectra, John Wiley and Sons, New Jersey, 2004.

[36] L.L. Olmsted, R.V. Kilambi, Age and growth of spotted bass (Micropterus punctulatus) in Lake Fort Smith, Arkansas, Trans. Am. Fish. Soc. 107 (1978) 21-25.

[37] L.F. Viana, Y.R. Súarez, S.E. Lima-Junior, Influence of environmental integrity on the feeding biology of Astyanax altiparanae Garutti \& Britski, 2000 in the Ivinhema river basin, Acta Sci. Biol. Sci. 35 (2013) (2000) 541-548.

[38] Y.A. Ovchínnikov, A.N. Shamin, Estructura y funciones de las proteínas, Editorial Mir, Moscú Rússia, 1986.

[39] A.H. Weatherley, H.S. Gill, The Biology of Fish Growth, Academic Press, London, 1987.

[40] L.A. Zavala-Camin, Introdução aos estudos sobre alimentação natural em peixes, EDUEM, Maringá, 1996.

[41] S.D. Gerking, Feeding Ecology of Fish, Academic Press, San Diego, California, 1994.

[42] M.C.F. Abelha, E. Goulart, E.A.L. Kashiwaqui, M.R. Silva, Astyanax paranae Eigenmann, 1914 (Characiformes: Characidae) in the Alagados Reservoir, Paraná, Brazil: diet composition and variation, Neotrop. Ichthyol. 4 (3) (2006) 349-356. 